\section{Posttransplant Irrigation Frequency Affects Growth of Container-grown Sweet Viburnum in Three Hardiness Zones}

\author{
Amy L. Shober ${ }^{1,7}$ \\ University of Florida, IFAS, Center for Landscape Conservation and \\ Ecology, Soil and Water Science Department, Gulf Coast REC, 14625 CR \\ 672, Wimauma, FL 33511 \\ Kimberly A. Moore ${ }^{2}$ \\ University of Florida, IFAS, Environmental Horticulture Department, Ft. \\ Lauderdale REC, 3205 College Avenue, Davie, FL 33314
}

Christine Wiese ${ }^{3}$

University of Florida, IFAS, Environmental Horticulture Department, 100 Mehrhof Hall, P.O. Box 110675, Gainesville, FL 32611

\section{S. Michele Scheiber \\ University of Florida, IFAS, Environmental Horticulture Department, MREC, 2725 Binion Road, Apopka, FL 32703}

Edward F. Gilman ${ }^{4}$ and Maria $\mathbf{P a z}^{3}$

University of Florida, IFAS, Environmental Horticulture Department, 100 Mehrhof Hall, P.O. Box 110675, Gainesville, FL 32611

Meghan M. Brennan ${ }^{5}$

University of Florida, IFAS, Department of Statistics, 418 McCarty Hall C, P.O. Box 110339, Gainesville, FL 32611-0339

\section{Sudeep Vyapari ${ }^{6}$ \\ Hillsborough Community College, Plant City Campus, 1206 N Park Road, Plant City, FL 33566}

Additional index words. water management, landscape management, root:shoot ratio

\begin{abstract}
The survival and quality of shrubs planted in the landscape from containers is dependent on irrigation to ensure the development of a healthy root system. This study determined the effect of irrigation frequency on survival, quality, canopy growth index, root to canopy spread ratio, and dry root and shoot biomass of Viburnum odoratissimum Ker-Gawl. (sweet viburnum) planted in Florida in USDA hardiness Zones $8 b$ (Citra, FL), 9a (Balm, FL), and 10b (Ft. Lauderdale, FL). Sweet viburnum shrubs were planted into the landscape from 11.4-L (\#3) containers and irrigated with $3 \mathrm{~L}$ every 2 , 4, or 8 days. Shrubs were planted on eight dates over a 2 -year period (2004 to 2006). Irrigation frequency during the 12- to 22-week irrigation period had no significant effect on sweet viburnum survival or aesthetic quality at any location. In addition, there was no irrigation effect on root spread, root to shoot biomass ratio, or root biomass for shrubs planted in Zones $8 \mathrm{~b}$ or 9a. However, sweet viburnum irrigated every 2 days had greater canopy growth index at 28 and 104 weeks after planting than shrubs irrigated every 4 or 8 days in Zone $8 \mathrm{~b}$ and every 8 days in Zone 9a. When planted in Zone 10b, sweet viburnum irrigated every 2 days exhibited greater growth index, shoot biomass, and root biomass than plant receiving irrigation every 4 days. Although more frequent irrigation (every 2 days) resulted in more plant growth in Zones $8 \mathrm{~b}$ and $\mathbf{1 0 b}$, sweet viburnum survived and grew after planting under natural rainfall conditions provided they were irrigated with $3 \mathrm{~L}$ of water every 8 days during establishment until roots reached the canopy edge in hardiness Zones $8 \mathrm{~b}$ and $9 \mathrm{a}$ and every 4 days in hardiness Zone 10b. Subsequent supplemental irrigation (hand-watering) was only needed after irrigation was ended when plants exhibited visible signs of drought stress and there was no measurable rainfall for $\mathbf{3 0}$ consecutive days.
\end{abstract}

Container-grown woody ornamental plants may not develop sufficient root systems to compensate for evapotranspiration losses if not properly irrigated during estab-

lishment in the landscape (Barnett, 1986; Gilman et al., 1996; Montegue et al., 2000). Some species of containerized shrubs can dry out quickly after planting because soil water potentials can reach levels that inhibit root growth within $2 \mathrm{~d}$ after planting (Costello and Paul, 1975). Therefore, the imposition of mandatory water restrictions may result in the failure of newly transplanted shrubs and trees to establish adequate root systems, leading to plant death and significant economic losses to nurseries and the landscaping industry.

Factors such as widespread installation of in-ground irrigation systems, rapid population growth, and frequent drought conditions have led to the adoption of mandatory outdoor water restrictions. In Florida, most water use restrictions allow daily irrigation of newly installed landscape plants for 30 to $60 \mathrm{~d}$ regardless of plant type (e.g., turfgrass, shrubs, trees, and bedding plants) (South Florida Water Management District, 2008; Southwest Florida Water Management District, 2008; St. Johns River Water Management District, 2008). This 30- to 60-d allowance is shorter than the period required for the successful establishment of trees and shrubs in the landscape. For example, the University of Florida-Institute of Food and Agricultural Sciences suggests that woody plants installed from 11.4-L (\# 3) containers should receive supplemental irrigation for 6 to 12 months after planting (Trenholm et al., 2002). A recent study conducted in Apopka, FL (USDA hardiness Zone 9b) indicated that Viburnum odoratissimum Ker-Gawl., Ilex cornuta Lindl. \& Paxt. 'Burfordii Nana', and Pittosporum tobira [Dryand] 'Variegata' grown in a rainout shelter required irrigation for a period of 16 to 20 weeks after planting (WAP) to ensure successful establishment in the landscape (Scheiber et al., 2007).

Several studies have shown that increasing the total volume of irrigation may not increase woody plant growth or quality. For example, Gilman et al. (1998) reported no difference in growth or stem water potential of transplanted Quercus virginiana Mill. when irrigated with 11,22 , or $33 \mathrm{~L}$ of water. Similarly, Welsh et al. (1991) reported no growth response of Photinia $\times$ fraseri in response to increased irrigation volume $(50 \%, 75 \%$, or $100 \%$ replacement of actual water use). In contrast, increasing irrigation frequency, with a concurrent increase in total irrigation volume, has been shown to affect growth of woody shrubs and trees (Gilman et al., 1996, 2009). Studies examining the effects of irrigation frequency have consistently shown an increase in woody plant growth in response to increased irrigation frequency and volume (Barnett, 1986; Gilman et al., 1996; Marshall and Gilman, 1998; Stabler and Martin, 2000). For example, canopy growth of Ligustrum vulgare L. increased from 0.03 to $0.14 \mathrm{~m}^{3}$ (1.0 to 4.9 $\mathrm{ft}^{3}$ ) when plants were irrigated every 5 $\mathrm{d}$ instead of every $10 \mathrm{~d}$ after an initial 28d period of daily irrigation (Barnett, 1986). Stabler and Martin (2000) reported a similar increase in growth of Caesalpinia pulcherrima L. and Cercidium floridum (Benth. ex A. Gray) S. Watson subsp. florida as irrigation frequency increased. Marshall and Gilman 
(1998) found an increase in both trunk diameter and height growth and root mass of Acer rubrum L. as irrigation frequency increased. Increased shoot growth as a response to increased irrigation frequency was also reported for Ilex cornuta 'Burfordii Nana', but root growth from the bottom of the root ball decreased (Gilman et al., 1996).

Although many studies have shown an increase in plant growth in response to increased irrigation frequency, most of the research in the southeastern United States has focused on trees, whereas shrub research has mainly been conducted in the western United States. There is a need to determine the impact of irrigation frequency on plant survival and aesthetic quality. The specific objective of this study was to determine the effect of irrigation frequency during establishment of $V$. odoratissimum on canopy growth, root growth, and aesthetic quality in the landscape in three USDA hardiness zones in Florida.

\section{Materials and Methods}

Experimental design. Viburnum odoratissimum Ker Gawl. plants obtained from a commercial nursery in 11.4-L (\# 3) smoothsided pots were planted at three sites in the state of Florida: 1) the Plant Science Research and Education Unit located in USDA hardiness Zone 8b (Citra, FL; long. $29^{\circ} 24^{\prime} 5.07^{\prime \prime} \mathrm{N}$, lat. $82^{\circ} 10^{\prime} 37.99^{\prime \prime} \mathrm{W}$; Arredondo sand, loamy, siliceous, semiactive, hyperthermic Grossarenic Paleudults); 2) the Gulf Coast Research and Education Center located in Zone 9a (Balm, FL; long. $27^{\circ} 45^{\prime} 40.32^{\prime \prime} \mathrm{N}$, lat. $82^{\circ} 13^{\prime} 40.14^{\prime \prime} \mathrm{W}$; Zolfo fine sand, sandy, siliceous, hyperthermic Oxyaquic Alorthods or Seffner fine sand, sandy, siliceous, hyperthermic Aquic Humic Dystrudepts); and 3) the Ft. Lauderdale Research and Education Center located in Zone 10b (Ft. Lauderdale, FL; long. $26^{\circ} 5^{\prime} 6.36^{\prime \prime} \mathrm{N}$, lat. $80^{\circ} 14^{\prime} 25.39^{\prime \prime} \mathrm{W}$; Margate fine sand, siliceous, hyperthermic Mollic Psammaquents). Shrubs were planted within a week of pickup and were in similar states of root growth in the container. Shrubs were planted Sept. 2004 and 2005, Dec. 2004 and 2005, Mar. 2005 and 2006, and June 2005 and 2006 for a total of eight planting dates. Shrubs were planted on $3.6-\mathrm{m}$ centers at

Received for publication 16 Apr. 2009. Accepted for publication 18 June 2009 .

The work was supported by the Florida Agricultural Experiment Station, the Florida Department of Agriculture and Consumer Services, the South Florida Water Management District, the Southwest Florida Water Management District, the St. Johns River Water Management District, and the Florida Nursery, Growers and Landscape Association.

${ }^{1}$ Assistant Professor.

${ }^{2}$ Associate Professor.

${ }^{3}$ Biological Scientist.

${ }^{4}$ Professor.

${ }^{5}$ Statistical Research Coordinator.

${ }^{6}$ Manager of Environmental Programs.

${ }^{7}$ To whom reprint requests should be addressed; e-mail alshober@ufl.edu. grade and root balls were left undisturbed at planting. Immediately after planting, 7.5- to $10-\mathrm{cm}$ long pieces of chipped urban waste wood or pine bark was applied as mulch at a 7.6-cm thickness in 1.8-m wide rows with the shrubs in the middle of the row. Shrubs were well-watered at planting and irrigation treatments started the day after planting.

Irrigation treatments were applied to six randomly chosen plant replicates at each location and planting date with the following frequencies: every 2,4 , or $8 \mathrm{~d}$. Irrigation was applied regardless of the timing and duration of rainfall events. The 8-d irrigation frequency was discontinued at the hardiness Zone 10b location (Ft. Lauderdale, FL) beginning with the Sept. 2005 planting as a result of unsatisfactory performance of the plants and therefore is not included in the data analysis or discussion. Each shrub was irrigated with $3 \mathrm{~L}$ of water per irrigation event using three bubbler emitters (Model Shrubbler $^{\circledR} 360^{\circ}$; Antelco ${ }^{\circledR}$, Longwood, FL). Previous work with shrubs showed little benefit from adding more volume (Gilman et al., 2009). Each emitter was mounted $10.2 \mathrm{~cm}$ aboveground level with an emitter located on the east and west side of each plant, $15 \mathrm{~cm}$ from the outside of the root ball, and the third emitter was positioned on the root ball. Irrigation frequencies were controlled as separate zones using an automated irrigation time clock (Model Sterling 12; Superior Controls Co., Inc., Valencia, CA) in Zones $9 \mathrm{a}$ and $10 \mathrm{~b}$ or a valve controller (Model SVC; Hunter ${ }^{\circledR}$ Industries Inc., San Marcos, CA) in Zone $8 \mathrm{~b}$. Irrigation in Zones $8 \mathrm{~b}$ and $10 \mathrm{~b}$ began at $0800 \mathrm{HR}$ and was completed by $0830 \mathrm{HR}$; irrigation in Zone 9a began at $0200 \mathrm{HR}$ and was completed by $0230 \mathrm{HR}$. Flow meters (Model C700; AMCO, Ocala, FL) were installed for each irrigation treatment as a safeguard to confirm the volume of water being applied to each plant. Irrigation was ended for each planting date, irrigation frequency, and site combination individually once sweet viburnum roots grew to the edge of the foliage canopy (within 12 to 22 WAP for all plantings). Previous work suggested that sweet viburnum could survive in Zone $8 \mathrm{~b}$ with little irrigation once roots reached the edge of the canopy (Gilman et al., 2009). The total volume of water applied to shrubs was $197 \pm 36 \mathrm{~L}$ for shrubs watered every $2 \mathrm{~d}, 98 \pm$ $18 \mathrm{~L}$ for shrubs watered every $4 \mathrm{~d}$, and $49 \pm$ $9 \mathrm{~L}$ for shrubs watered every $8 \mathrm{~d}$.

After automated irrigation was ended (12 to 22 WAP, as appropriate), supplemental irrigation (3 L per plant by hand) was only supplied to all shrubs for a specific planting date over the 2-year postplanting period only when signs of severe water stress (severe foliage wilting) were apparent. Supplemental irrigation was applied only when rainfall was less than $6 \mathrm{~mm}$ in any 24-h period consecutively for $32 \mathrm{~d}$ (Fig. 1). The maximum amount of supplemental irrigation applied to shrubs for any specific planting date was 6 L. Cumulative monthly rainfall data were collected at each planting location from Florida Automated Weather Network sta- tions located within $50 \mathrm{~m}$ of the planting sites (Fig. 1). Historical monthly rainfall volumes were collected from the National Oceanic and Atmospheric Administration (National Oceanic and Atmospheric Administration, 2002)

All plots were fertilized every 3 months (beginning $30 \mathrm{~d}$ after planting) with $12 \mathrm{~N}-$ 0.9P-11.6K Southern Ornamental and Landscape fertilizer (LESCO, Inc., Cleveland, $\mathrm{OH})$ controlled-released fertilizer at an $\mathrm{N}$ rate of $0.45 \mathrm{~kg} / 100 \mathrm{~m}^{2}$. Fertilizer was broadcast over a $0.84-\mathrm{m}^{2}$ area around each shrub. Weeds were controlled by hand or with periodic applications of $N$-(phosphonomethyl) glycine (glyphosate, Roundup Pro; Monsanto Company, St. Louis, MO). Shrubs were not pruned during the study.

Plant survival and quality. Plant survival was documented at 28, 52, and 104 WAP. In addition, quality (plant density and dieback) was visually rated on a scale of 1 (dead plant) to 9 (dense, full canopy with no dieback).

Growth index. Growth index (GI) was used as a quantitative indicator of plant growth. Growth index for each plant was calculated as: GI $\left(\mathrm{m}^{3}\right)=\mathrm{H} \times \mathrm{W} 1 \times \mathrm{W} 2$, in which $\mathrm{H}$ is the plant height $(\mathrm{m}), \mathrm{W} 1$ is the widest width of the plant (m), and W2 is the width perpendicular to the widest width $(\mathrm{m})$. Growth index was measured on three plant replicates per treatment at 0 (date of planting), 28, 52, and 104 WAP.

Root spread and root to canopy spread ratio. Root spread was measured on three plant replicates per irrigation frequency at 28, 52 , and 104 WAP by excavating the longest root (near the soil surface) on the east and west sides of the plant and measuring its length from the base of the plant. Roots were excavated by gently removing the mulch layer from a section of soil $\approx 30 \mathrm{~cm}$ wide and $100 \mathrm{~cm}$ from the base of the plant and gently digging by hand toward the plant until the outermost new roots were identified. Root spread radius was then calculated as the mean of the east and west root lengths \{root spread radius $(\mathrm{cm})=1 / 2 \times$ [east root length $(\mathrm{cm})+$ west root length $(\mathrm{cm})]\}$. Root to canopy spread ratio was then calculated as: root:canopy spread ratio (unitless) $=$ root spread radius $(\mathrm{cm}) /$ mean canopy radius $(\mathrm{cm})$, with mean canopy radius $(\mathrm{cm})=1 / 4 \times(\mathrm{W} 1+\mathrm{W} 2)$.

Harvest biomass. The entire aboveground canopy (shoots) was harvested from three plant replicates per irrigation treatment per planting date at 52 and 104 WAP. Two wedge-shaped sections of soil containing approximately $1 / 8$ (Zones $8 \mathrm{~b}$ and $10 \mathrm{~b}$ ) or $1 / 4$ (Zone $9 \mathrm{a}$ ) of the irrigated soil volume containing roots (extending beyond the original root ball) were excavated from northeast and southwest sides of the same shrubs where the canopy was harvested. Soil was removed using a sieve and all root matter was collected. The harvested shoots and roots were dried to a constant mass at $105 \pm 5{ }^{\circ} \mathrm{C}$. The dry mass of shoots and roots was recorded. The total mass of the root system was estimated by: root mass $(\mathrm{g})=$ dry root mass harvested $\times 8$ (Zones $8 \mathrm{~b}$ and $10 \mathrm{~b}$ ) or root 

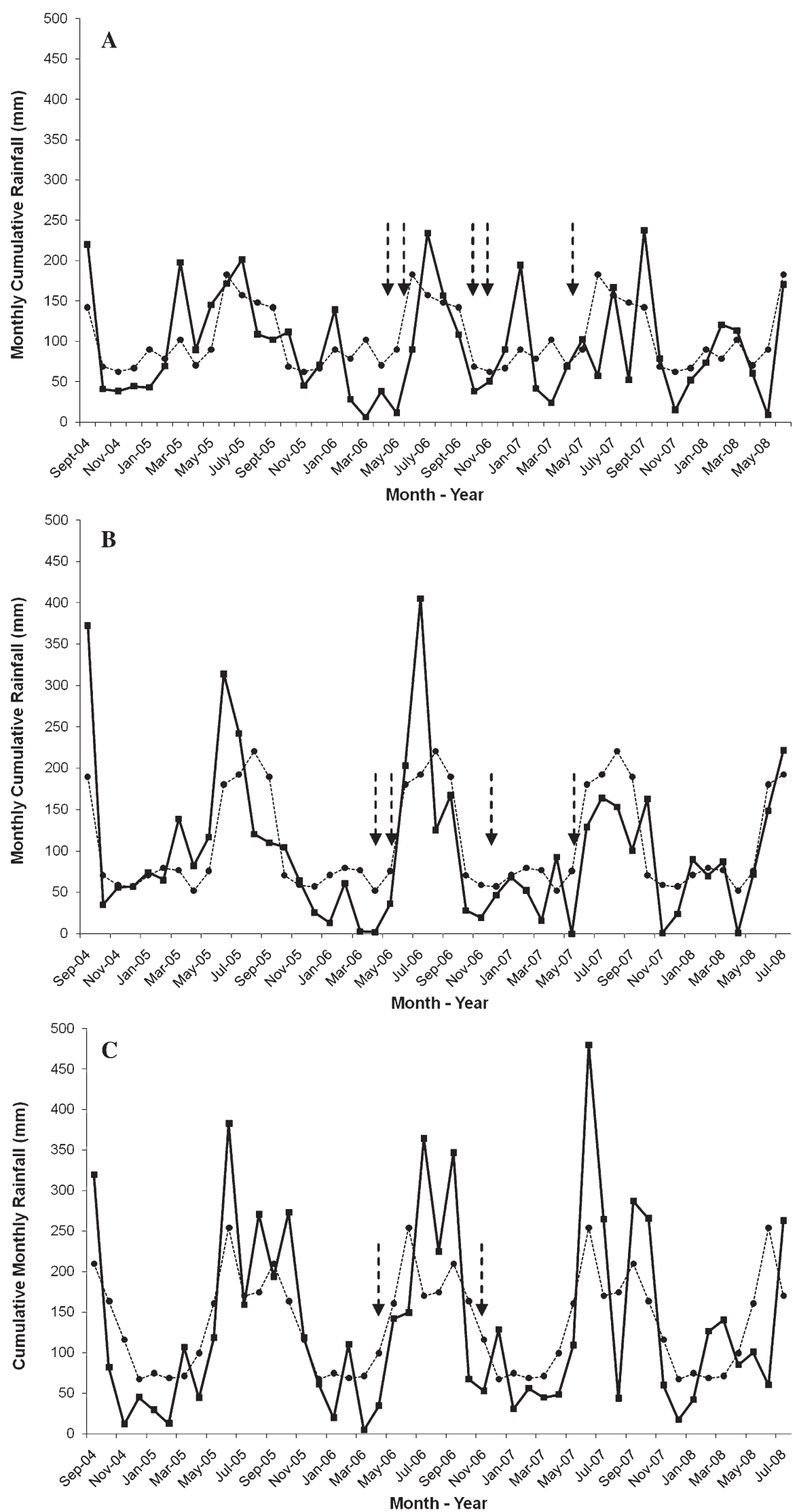

Fig. 1. Actual cumulative monthly rainfall (solid line), historical monthly rainfall (dashed line), and supplemental irrigation applications (dashed arrows) received by field planted Viburnum odoratissimum Ker Gawl (sweet viburnum) in USDA hardiness Zone (A) 8b (Citra, FL), (B) 9a (Balm, FL), and (C) $10 b$ (Ft. Lauderdale, FL). mass $(\mathrm{g})=$ dry root mass harvested $\times 4$ (Zone 9a). The root to shoot biomass ratio was then calculated as: root:shoot biomass ratio (unitless $)=$ root mass $(\mathrm{g}) /$ shoot mass $(\mathrm{g})$.

Data analysis. The experiment was designed as a randomized complete block design with three irrigation frequencies applied randomly to six plant replicates within each planting date (planting date $=$ block) Planting date was included in the model as a random effect because the field position for each of the eight plantings was assigned randomly at each location. Data were analyzed separately for each hardiness zone (location) in Florida at 28, 52, and 104 WAP (as applicable). Plant survival was analyzed using the PROC GLIMMIX program in SAS (SAS Institute, 2003) using the binomial distribution and the logit link function. Plant quality data were analyzed using the PROC GLIMMIX program in SAS (SAS Institute, 2003) with the multinomial distribution and the cumulative logit link function. Shrub growth index, root spread radius, root:canopy spread ratio, and harvest biomass (dry roots and dry shoots) were analyzed using the PROC MIXED procedure in SAS (SAS Institute, 2003). For analysis of GI, initial GI (0 WAP) was included in the model as a covariate to account for variation in initial plant size at different planting dates. All pairwise comparisons were completed using the Tukey honestly significant difference test with a significance level of $\alpha=0.05$.

\section{Results and Discussion}

Plant survival and quality. Twenty-five percent of sweet viburnum planted in Zone 10a between Sept. 2004 and June 2005 that were irrigated every $8 \mathrm{~d}$ were dead by 52 WAP compared with $0 \%$ and $8.3 \%$ of the plants irrigated every 2 and $4 \mathrm{~d}$, respectively. These results were similar to those reported by Scheiber et al. (2007), in which more than half the sweet viburnum irrigated every $7 \mathrm{~d}$ under a rainout shelter died by 16 WAP Therefore, 8-d irrigation treatment was removed from the study in Zone $10 \mathrm{~b}$ because it resulted in too many dead plants for most landscape applications.

Irrigation frequency during establishment had no significant effect on survival of fieldplanted sweet viburnum at any location (data not shown). Irrigation frequency also had no significant effect on sweet viburnum quality at any location at 28, 52, or 104 WAP (data not shown) despite a large variation in the total volume of irrigation applied (mean volume of 197,98 , and $49 \mathrm{~L}$ for shrubs watered every 2, 4, and $8 \mathrm{~d}$, respectively). These results differ from those of Scheiber et al. (2007), who reported that the aesthetic quality of sweet viburnum was reduced when irrigated every $7 \mathrm{~d}$ when compared with plants watered every 2 or $4 \mathrm{~d}$. However, the study by Scheiber et al. (2007) was conducted under a rainout shelter, thereby eliminating the effect of rainfall events. In our study, plants received irrigation as a supplement to natural rainfall events (Fig. 1). Fitzpatrick 
and Burch (1986) initially observed differences in Murraya paniculata L. Jack quality as a result of irrigation frequency (zero, one, or three times per week), but the effect was temporary, and there was no difference in quality after 2 months in the field. The authors attributed the lack of irrigation effect on quality after 2 months to the influence of rainfall events. Paine et al. (1992) also reported no significant effect of irrigation frequency (irrigated every 1, 3, 5, or $7 \mathrm{~d}$ ) on visual appearance (aesthetics) of Ceanothus griseus var. horizontalis (Trel.) McMinn, Rhamnus californica (Eschsch.) A. Gray, and Photinia $\times$ fraseri Dress when plants received the same total volume $(522 \mathrm{~L})$ of irrigation.

Growth index. Irrigation frequency affected GI of sweet viburnum at 28 and 104 WAP when planted in Zones $8 \mathrm{~b}$ and 9a. For shrubs planted in Zone 8 b, irrigating every $2 \mathrm{~d}$ resulted in larger plants than irrigating every 4 or $8 \mathrm{~d}$ (Table 1 ). These results are supported by the findings of Scheiber et al. (2007), which reported that sweet viburnum plants grown in a rainout shelter in Apopka, FL (Zone 9b) and irrigated every $2 \mathrm{~d}$ were larger than plants irrigated every 4 or $7 \mathrm{~d}$ with 9 L of water per irrigation event. Shrubs irrigated every $2 \mathrm{~d}$ were larger than those irrigated every $8 \mathrm{~d}$ when planted in Zone 9a; however, there was no difference in GI for plants irrigated every 2 and $4 \mathrm{~d}$ (Table 1 ). Similarly, differences in GI for shrubs irrigated using the 2- and 4-d frequencies in Zone $10 \mathrm{~b}$ were not significant at 28,52 , or 104 WAP (Table 1). These results were different from those reported by Scheiber et al. (2007), probably as a result of the influence of rainfall events in our study (Fig. 1) or climatic differences.

Other studies also confirm that frequently irrigated woody plants in the landscape respond with greater growth (e.g., trunk diameter, crown spread, height) than infrequently irrigated plants (Gilman et al., 1998; Marshall and Gilman, 1998; Stabler and Martin, 2000). Paine et al. (1992) reported no significant difference in growth of Ceanothus griseus var. horizontalis, Rhamnus

Table 1. Mean growth index for $V$. odoratissimum irrigated every 2,4 , or $8 \mathrm{~d}$ averaged over eight planting dates over a 2-year period in USDA hardiness Zones 8b, 9a, and 10b.

\begin{tabular}{|c|c|c|c|}
\hline \multirow{2}{*}{$\begin{array}{l}\text { Irrigation } \\
\text { frequency }\end{array}$} & \multicolumn{3}{|c|}{ Growth index $\left(\mathrm{m}^{3}\right)$} \\
\hline & $28 \mathrm{WAP}^{\mathrm{y}}$ & 52 WAP & $104 \mathrm{WAP}$ \\
\hline & \multicolumn{3}{|c|}{ Hardiness Zone $8 b$} \\
\hline $2 \mathrm{~d}$ & $0.42 \mathrm{a}^{\mathrm{x}}$ & $0.91 \mathrm{a}$ & $4.01 \mathrm{a}$ \\
\hline $4 \mathrm{~d}$ & $0.32 \mathrm{~b}$ & $0.78 \mathrm{a}$ & $3.33 \mathrm{~b}$ \\
\hline \multirow[t]{2}{*}{$8 \mathrm{~d}$} & $0.32 \mathrm{~b}$ & $0.75 \mathrm{a}$ & $3.24 \mathrm{~b}$ \\
\hline & \multicolumn{3}{|c|}{ Hardiness Zone $9 a$} \\
\hline $2 \mathrm{~d}$ & $0.42 \mathrm{a}$ & $0.68 \mathrm{a}$ & $2.52 \mathrm{a}$ \\
\hline $4 \mathrm{~d}$ & $0.39 \mathrm{ab}$ & $0.70 \mathrm{a}$ & $2.10 \mathrm{ab}$ \\
\hline \multirow[t]{2}{*}{$8 \mathrm{~d}$} & $0.35 \mathrm{~b}$ & $0.59 \mathrm{a}$ & $1.87 \mathrm{~b}$ \\
\hline & \multicolumn{3}{|c|}{ Hardiness Zone $10 \mathrm{~b}$} \\
\hline $2 \mathrm{~d}$ & $0.51 \mathrm{a}$ & $0.71 \mathrm{a}$ & $2.96 \mathrm{a}$ \\
\hline $4 \mathrm{~d}$ & $0.50 \mathrm{a}$ & $0.80 \mathrm{a}$ & $3.20 \mathrm{a}$ \\
\hline
\end{tabular}

${ }^{\mathrm{z}}$ Growth index $=$ height $\times$ width $1 \times$ width 2 .

${ }^{\mathrm{y}} \mathrm{WAP}=$ weeks after planting.

${ }^{\mathrm{x}}$ Mean separations within a column and hardiness zone using Tukey $(P=0.05)$. californica, and Photinia $\times$ fraseri as a result of irrigation frequency (every 1, 3, 5, or $7 \mathrm{~d}$ ). However, all plants studied by Paine et al. (1992) received the same total volume of water [522 L or $63.8 \%$ reference evapotranspiration $\left.\left(\mathrm{ET}_{\mathrm{o}}\right)\right]$ over the 14-week period regardless of irrigation frequency, whereas the plants in our study and the other studies that support our findings (Gilman et al., 1998; Marshall and Gilman, 1998; Stabler and Martin, 2000) received less water when irrigation frequency was reduced.

Root spread and root:canopy spread ratio. Applying irrigation to the root ball and to a small area around the root ball did not restrict roots to this volume of soil; roots grew freely into soil outside this area. Irrigation frequency did not affect the root spread radius of sweet viburnum planted in Zones $8 \mathrm{~b}$ or 9a (data not shown). However, roots spread farther from the base of the shrub by 52 WAP when plants grown in Zone $10 \mathrm{~b}$ were irrigated every 2 d compared with those irrigated every $4 \mathrm{~d}$ (data not shown). Barnett (1986) also reported that roots of frequently irrigated [frequent irrigation schedule: daily (0-4 WAP), every $5 \mathrm{~d}$ (511 WAP), and every $6 \mathrm{~d}$ (11-21 WAP)] Ligustrum vulgare 'Lodense' extended an average of $45 \mathrm{~cm}$ from the plant crown by $21 \mathrm{WAP}$ compared with only $30 \mathrm{~cm}$ for plants irrigated less frequently [reduced irrigation schedule: daily (0-4 WAP), every $10 \mathrm{~d}$ (5-11 WAP), and every $12 \mathrm{~d}(11-21$ WAP)]. Roots of shrubs (Barnett, 1986) and trees (Marshall and Gilman, 1998) growing in moist temperate climates spread far beyond the area of soil that was moistened during irrigation events, indicating that wetting the root ball and soil immediately around the root ball provides plants with the capacity to explore a large volume of soil beyond the wetted zone.

Irrigation frequency also had no effect on root:canopy spread ratio for sweet viburnum planted in Zones 8b or 9a (data not shown). In Zone 10b, sweet viburnum irrigated every $4 \mathrm{~d}$ had a larger root:canopy spread ratio by 28 WAP (1.2). Although these results were statistically significant, the biological significance is unclear; however, a larger root:canopy spread ratio may suggest that shrubs irrigated every $4 \mathrm{~d}$ experienced a period of active root growth and decreased shoot growth compared with plants irrigated every
$2 \mathrm{~d}(1.0)$. By $52 \mathrm{WAP}$, this trend was reversed (and it held through 104 WAP), in which plants watered every $2 \mathrm{~d}$ had a higher root:canopy spread ratio (2.2 and 3.0 at 52 and 104 WAP, respectively) than those irrigated every $4 \mathrm{~d}$ (1.4 and 1.8 at 52 and 104 WAP, respectively). By 28 WAP, shrubs planted in all three hardiness zones had a root:canopy spread ratio greater than 1.0. Studies have suggested that trees are fully established once root:canopy spread ratio reaches a value between 1.7 and 3 (Gilman, 1998). Four cultivars of Juniperus chinensis L. reached a mean root:canopy spread ratio of 2.753 years after planting; ratios varied from $\approx 1.0$ to 4.3 depending on the shape of the canopy (Gilman and Kane, 1991). Juniper cultivars with a wide spreading canopy form ('Pfitzeriana' and 'Hetzii') had a lower root:canopy ratio (root:canopy spread ratio $\approx 1.0$ to 2.2) compared with cultivars with a more upright canopy (root:canopy spread ratio $\approx 2.0$ to 4.3 ). Therefore, our sweet viburnum shrubs, which have a wide spreading canopy, may have been nearly established by 28 WAP. Establishment at 28 WAP is further supported by continued root and shoot growth without a decline in quality through 104 WAP with limited (five, four, and two times in hardiness Zones $8 \mathrm{a}, 9 \mathrm{a}$, and 10b, respectively) supplemental irrigation applied only when measureable rainfall was absent for more than 32 consecutive days (Fig. 1). Gilman et al. (2009) reported that shrubs planted in the landscape from 11.4-L containers began declining (after the cessation of regular irrigation at $11 \mathrm{WAP}$ ) when rainfall was absent for $35 \mathrm{~d}$.

Harvest biomass. Root:shoot biomass ratio was unaffected by irrigation frequency for sweet viburnum grown in Zones $8 \mathrm{~b}$ and 9a. In Zone 10b, the root:shoot biomass ratio was larger at 104 weeks after transplanting for plants irrigated every $2 \mathrm{~d}$ as a result of increased root biomass for these plants compared with the plants irrigated every $4 \mathrm{~d}$ (data not shown).

Irrigation frequency did not affect dry shoot biomass for sweet viburnum planted in Zone 9a (Table 2). In Zone 8b, plants irrigated every $2 \mathrm{~d}$ produced significantly more dry shoot biomass at 52 and 104 WAP compared with plants irrigated every 4 and 8

Table 2. Dry shoot and root biomass for $V$. odoratissimum irrigated every 2, 4, or $8 \mathrm{~d}$ averaged over eight planting dates over a 2-year period in USDA hardiness Zones 8b, 9a, and 10b.

\begin{tabular}{|c|c|c|c|c|}
\hline \multirow{2}{*}{$\begin{array}{l}\text { Irrigation } \\
\text { frequency }\end{array}$} & \multicolumn{2}{|c|}{ Shoot biomass (g) } & \multicolumn{2}{|c|}{ Root biomass (g) } \\
\hline & $52 \mathrm{WAP}^{\mathrm{z}}$ & $104 \mathrm{WAP}$ & $52 \mathrm{WAP}$ & $104 \mathrm{WAP}$ \\
\hline & \multicolumn{4}{|c|}{ Hardiness Zone $8 b$} \\
\hline $2 \mathrm{~d}$ & $820 a^{y}$ & $4,367 \mathrm{a}$ & $458 \mathrm{a}$ & $955 \mathrm{a}$ \\
\hline $4 \mathrm{~d}$ & $685 \mathrm{ab}$ & $3,653 \mathrm{ab}$ & 298 a & $892 \mathrm{a}$ \\
\hline \multirow[t]{2}{*}{$8 \mathrm{~d}$} & $630 \mathrm{~b}$ & $3,373 \mathrm{~b}$ & $329 \mathrm{a}$ & $904 \mathrm{a}$ \\
\hline & \multicolumn{4}{|c|}{ Hardiness Zone 9a } \\
\hline $2 \mathrm{~d}$ & $817 \mathrm{a}$ & $2,789 \mathrm{a}$ & $874 \mathrm{a}$ & $626 \mathrm{a}$ \\
\hline $4 \mathrm{~d}$ & $751 \mathrm{a}$ & $3,079 \mathrm{a}$ & $738 \mathrm{a}$ & $543 \mathrm{a}$ \\
\hline \multirow[t]{2}{*}{$8 \mathrm{~d}$} & $726 \mathrm{a}$ & $2,186 \mathrm{a}$ & $687 \mathrm{a}$ & $487 \mathrm{a}$ \\
\hline & \multicolumn{4}{|c|}{ Hardiness Zone $10 b$} \\
\hline $2 \mathrm{~d}$ & $664 \mathrm{a}$ & $1,496 \mathrm{a}$ & $870 \mathrm{a}$ & $1,642 \mathrm{a}$ \\
\hline $4 \mathrm{~d}$ & $401 \mathrm{~b}$ & $1,197 \mathrm{a}$ & $592 \mathrm{~b}$ & $846 \mathrm{~b}$ \\
\hline
\end{tabular}

${ }^{\mathrm{z}} \mathrm{WAP}=$ weeks after planting.

${ }^{\mathrm{y}}$ Mean separations within a column and hardiness zone using Tukey $(P=0.05)$. 
d (Table 2). There was also a significant irrigation frequency effect on shoot biomass for shrubs grown in Zone 10b, in which plants irrigated every $2 \mathrm{~d}$ produced more shoot biomass than plants irrigated every $4 \mathrm{~d}$ by 52 WAP (Table 2). Pour et al. (2005) also reported up to a $50 \%$ to $68 \%$ increase in stem and leaf dry biomass for Pistacia vera L. when irrigation was applied daily compared with every 3 or $7 \mathrm{~d}$, respectively.

Irrigation frequency did not affect dry root biomass for sweet viburnum planted in Zones $8 \mathrm{~b}$ or 9a (Table 2). In Zone 10b, irrigation applied every $2 \mathrm{~d}$ resulted in more root biomass at 52 and 104 WAP than from plants irrigated every $4 \mathrm{~d}$ (Table 2). Similarly, Marshall and Gilman (1998) reported that frequently irrigated [frequent irrigation schedule: 38 L of water daily (2-9 WAP) and every 2 d (10-24 WAP)] Acer rubrum L. trees had more new root biomass 5 months after transplant than trees receiving less frequent irrigation [reduced irrigation schedule: $38 \mathrm{~L}$ of water every $7 \mathrm{~d}$ (2-3 WAP), every $3 \mathrm{~d}$ (4-9 WAP), every $10 \mathrm{~d}$ (10-19 WAP), and no irrigation (20-24 WAP)]. Similar results were also reported for Pistacia vera L. (Pour et al., 2005), Acer nigrum Michx., and Acer saccharum Marsh. (Graves, 1994).

\section{Conclusions}

Our data suggest that there was a growth response to supplemental irrigation even when rainfall was available to newly planted sweet viburnum in the moist Florida climate. This supplemental irrigation is needed to ensure the root ball remains moist enough to allow root growth into the surrounding landscape soil. Based on our results, we suggest that sweet viburnum can survive and grow after planting in Florida on natural rainfall alone provided the root ball and adjacent soil is irrigated with $3 \mathrm{~L}$ of water per irrigation event at a frequency of every 8 $\mathrm{d}$ (Zone $8 \mathrm{~b}$ and $9 \mathrm{a}$ ) or every $4 \mathrm{~d}$ (Zone $10 \mathrm{~b}$ ) until the roots reach the canopy edge $(\approx 20$ to 28 weeks after planting). Increasing the irrigation frequency to every $4 \mathrm{~d}$ in Zones $8 \mathrm{~b}$ and $9 \mathrm{a}$ and every $2 \mathrm{~d}$ in Zone $10 \mathrm{~b}$ may enhance plant growth but will not affect plant survival or quality. Once the roots extend to the edge of the canopy, supplemental irrigation of sweet viburnum may be required during periods of drought that exceed $30 \mathrm{~d}$ to ensure survival and prevent a decline in plant quality.

\section{Literature Cited}

Barnett, D. 1986. Root growth and water use by newly transplanted woody landscape plants. The Public Garden 1:23-25.

Costello, L. and J.L. Paul. 1975. Moisture relations in transplanted container plants. HortScience 10:371-372.

Fitzpatrick, G. and D. Burch. 1986. Interactive effects of nursery and landscape irrigation rates in growth and establishment of two landscape ornamentals. Proc. Florida State Hort. Soc. 99:159-161.

Gilman, E.F. 1998. Predicting root spread from trunk diameter and branch spread. J. Arboriculture 14:85-88.

Gilman, E.F., R.J. Black, and B. Dehgan. 1998. Irrigation volume and frequency and tree size affect establishment rate. J. Arboriculture 24:1-9.

Gilman, E.F. and M.E. Kane. 1991. Growth dynamics following planting of cultivars of Juniperus chinensis. J. Amer. Soc. Hort. Sci. 116:637-641.

Gilman, E.F., C.L. Wiese, M. Paz, A.L. Shober, S.M. Scheiber, K.A. Moore, and M.M. Brennan. 2009. Effects of irrigation volume and frequency on shrub establishment in the landscape. J. Environ. Hort. (in press)

Gilman, E.F., T.H. Yeager, and D. Weigle. 1996. Fertilizer, irrigation and root ball slicing affects Burford holly growth after planting. J. Environ. Hort. 14:105-110.

Graves, W.R. 1994. Seedling development of sugar maple and black maple irrigated at various frequencies. HortScience 29:12921294.

Marshall, M.D. and E.F. Gilman. 1998. Effects of nursery container type on root growth and landscape establishment of Acer rubrum L. J. Environ. Hort. 16:55-59.

Montegue, T., R. Kjelgren, and L. Rupp. 2000. Gas exchange and growth of two transplanted, field- grown tree species in an arid climate. HortScience 35:736-768

National Oceanic and Atmospheric Administration. 2002. Monthly station normals of temperature, precipitation, and heating and cooling degree days 1971-2000:08. Florida, Ashville. 24 Mar. 2009. <http://cdo.ncdc.noaa.gov/climatenormals/ clim81/FLnorm.pdf $>$.

Paine, T.D., C.C. Hanlon, D.R. Pittenger, D.M. Ferrin, and M.K. Malinoski. 1992. Consequences of water and nitrogen management on growth and aesthetic quality of drought-tolerant woody landscape plants. J. Environ. Hort. 10:94-99.

Pour, A.T., A.R. Sepaskhah, and M. Maftoun. 2005. Plant water relations and seedling growth of three pistachio cultivars as influenced by irrigation frequency and applied potassium. J. Plant Nutr. 28:1413-1425.

SAS Institute. 2003. SAS/STAT 9 and 9.1 users guide. SAS Institute, Cary, NC.

Scheiber, S.M., E.F. Gilman, M. Paz, and K.A. Moore. 2007. Irrigation affects landscape establishment of Burford holly, pittosporum, and sweet viburnum. HortScience 42:344-348.

South Florida Water Management District. 2008. Watering restrictions. South Florida Water Mgt. District, West Palm Beach. 22 Dec. 2008. <https://my.sfwmd.gov/portal/page? pageid=1874,9496104,1874_19616129\&_dad= portal\&_schema $=$ PORTAL $>$.

Southwest Florida Water Management District. 2008. Water restrictions. Southwest Florida Water Mgt. District, Brooksville. 22 Dec. 2008. $<$ http://www.swfwmd.state.fl.us/conservation/ restrictions $>$.

St. Johns River Water Management District. 2008. Drought information and irrigation rule. St. Johns River Water Mgt. District, Palatka. 22 Dec. 2008. <http://sjr.state.fl.us/irrigationrule/ index.html $>$.

Stabler, L.B. and C.A. Martin. 2000. Irrigation regimens differentially affect growth and water use efficiency of two southwest landscape plants. J. Environ. Hort. 18:66-70.

Trenholm, L.E., E.F. Gilman, G.W. Knox, and R.J. Black. 2002. Fertilization and irrigation needs for Florida lawns and landscapes. ENH860. Univ. Florida Inst. Food Agr. Sci., Gainesville, FL.

Welsh, D.F., J.M. Zajicek, and C.G. Lyons, Jr. 1991. Effect of seasons and irrigation regimes on plant growth and water-use of container-grown Photinia $\times$ fraseri. J. Environ. Hort. 9:79-82. 